\title{
Kentsel Dönüșümde Finansman Yöntemleri ve Kamu Müdahalesi
}

Neslihan KOC̣'

Makale Gönderim Tarihi: 19.11.2018

Makale Kabul Tarihi: 10.03.2019

\section{Öz}

Türkiye'de artan nüfusun ihtiyaçlarına cevap verecek bir konut üretiminin yanı sıra riskli olarak belirlenmiș yaklașık on dört milyon konutun yenilenmesi ya da güçlendirilmesi için önemli bir finansman ihtiyacı bulunmaktadır. Sağlıklı bir konut politikasının yürütülebilmesi ve kentsel dönüșümün gerçekleștirilebilmesi için yürürlükteki araçlar dıșında yeni maliye ve finansman araçlarının yürürlüğe konulması ve yaygınlaștırılması gerekmektedir. Çalıșmada, kentsel dönüșümle ilgili tarafların kullanabilecekleri yeni finansman yöntemlerinin neler olabileceği ele alınmıștır. Literatür incelemesi sonucu ulașılan yeni yaklașımlar olarak, gayrimenkule dayalı sermaye piyasası araçları ve değer yakalama yöntemleri, kentsel dönüșüm finansmanında ülkemizde uygulanması önerilen araçlardır.

Anahtar Kelimeler: Kentsel Dönüșüm, Kentsel Dönüșüm Finansmanı, Değer Yakalama Yöntemleri

\section{Financing Methods and Public Intervention in Urban Transformation}

\section{Abstract}

Turkey has a significant financing requirement for residential construction, which will satisfy the needs of the growing population, in addition to the financing requirement for the replacement or reinforcement of nearly fourteen million residencies, which were identified as risky. In order to sustain a healthy housing policy and to be able to realize urban transformation; there is need to put new public and private financing tools into action, as well as to generalize them. In the study, potential new financing methods that can be used by the parties related to urban

Dr. Öğr. Üyesi, Hitit Üniversitesi, İktisadi ve İdari Bilimler Fakültesi Maliye Bölümü, neslihankoc@hitit.edu.tr, Orcid: 0000-0002-7722-6978 
transformation are discussed. As a result of the literature review, real estate based capital market instruments and value capture methods are the tools proposed in Turkey in the financing of urban transformation.

Keywords: Urban Transformation, Urban Transformation Financing, Value Capture Methods

JEL Classification Codes: R52, R3 1, R5 1

\section{Giriș}

Kentsel dönüșüm, inșaat, bankacılık, finans gibi ekonomideki birçok sektörü, hem merkezi hem yerel düzeydeki birimleri, șehir planlama, mimarlık, sosyoloji, ekonomi, finans gibi birçok bilim alanını ilgilendirmekte ve bireylerin yașam kaliteleri ve refah düzeylerini etkilemektedir. Bu açıdan pek çok yönüyle ele alınabilecek bir alandır. Toplum açısından konut politikalarının öncelikli yapısı, kentsel dönüșümün gündemdeki yeri, ekonomi içindeki önemi ve katlanılması gereken yüksek maliyetler, devletin bu alana çeșitli șekillerde müdahil olmasına sebep olmaktadır. Özellikle hukuki çerçevenin belirlenmesi ve finansman destekleri bu müdahalede ön plana çıkmaktadır. Çünkü planların yapılması, binaların yıkımı, bakımı, restorasyonu gibi ișlemler, hem tarafların hukuki olarak korunmasıyla hem de finansal olarak parasal kaynak sağlanmasıyla doğrudan ilgilidir. Farklı finansman biçimlerinin yaygınlaștırılması ile devletin uygulamada sağlayacağı her türlü hukuki, ekonomik ve mali kolaylık, kentsel dönüșüm uygulamalarının artmasına katkıda bulunarak kentsel dönüșümden beklenen fiziki ve ekonomik gelișmeyi doğrudan; sosyal ve kültürel gelișmeyi ise dolaylı olarak olumlu etkileyecektir.

Çalıșmanın amacı, kentsel dönüșümün önemini vurgulamak, devletin bu alanda kullandığı düzenleyici araçları belirlemek ve kullanabileceği düșünülen araçları literatüre kazandırmaktır. Çalıșmadaki en önemli sınırlılıklardan biri, kentsel dönüșümle ilgili verilerin sayısal analiz yapılacak düzeyde var olmamasıdır. Bu açıdan nitel değerlendirmelere yer verilmiștir. İkinci olarak konunun geniș kapsamlı olmasından dolayı devlet müdahalesinin genel teorisine yer verilmemiș, odak konu ile sınırlı tutulmuștur. Çalıșmada ilk bölümde kentsel dönüșüm kavramı açıklanarak nedenlerine yer verilmiștir. Kentsel dönüșüme kamu müdahalesinin nedenleri ve Türkiye'de kentsel dönüșümün gerekliliği ikinci bölümde yer almaktadır. Üçüncü bölümde Türkiye'deki ve diğer ülke uygulamalarında yer alan müdahale ve finansman araçları ele alınarak açıklanmıștır. 


\section{Kentsel Dönüșüm Kavramı}

Günümüzde üretim merkezi olma özellikleri azalan kentler, birer hizmet ve tüketim merkezine dönüșmektedir. Kent merkezlerinde yer alan fonksiyonlar, desantralize olarak merkez dıșına ve kent çeperlerine çekilmektedir (Couch vd, 2003). Ancak bu değișim, kent yoğunluğunun azalması sonucunu yaratmamakta; kentler sürekli büyümektedir. Kentlerde artan talebin karșılanmasında iki temel seçenek gündeme gelmektedir. Bunlardan birincisi kentlerin fiziki olarak büyütülmesi, ikincisi kent merkezlerinin yoğunlaștırılmasıdır. Kentsel dönüșümde mekânsal olarak kentleri büyütmek yerine var olanı düzeltme amacı ön plandadır. Bu açıdan kentsel dönüșüm, özel sektörün ve toplumun katılımıyla yerel yönetimlerin koșulları iyileștirmek ve artan nüfusun ihtiyaçlarını ve ekonomik faaliyetlerini karșılamak için kent çeperlerinde yeni kentsel alanlar geliștirmelerinin tersine, var olan bir kentsel alanın kullanımını artırmak için yaptıkları çeșitli müdahaleler (Amirtahmasebi vd, 2016: xv-xvi) șeklinde tanımlanabilir. Azalan kentsel arazilerin yenilenmesi, kentlerin sürdürülebilir gelișimine katkıda bulunmaktadır.

Her kentte cazibesini yitirmiș eski iș merkezi alanları, kentsel sit alanları gibi az kullanılan/ yeterince kullanılmayan topraklar, gecekondu mahalleleri ve pek çok sosyal, kriminal ve mekânsal sorunu barındıran konut alanları gibi yașam kalitesi düșük, sıkıntılı ve çürüyen kentsel alanlar bulunmaktadır. Genellikle nüfus artıșı, sanayileșme, kentsel büyüme ve verimlilik modellerinde meydana gelen değișikliklerin sonucu olarak olușan bu çöküntü alanları, kentin imajını, yașanabilirliğini ve verimliliğini zayıflatmaktadır. Az kullanılan kentsel arazilerin geliștirilmesi, kentsel alanlarda ekonomik, sosyal ve fiziksel bozulma sürecinin tersine çevrilmesini gerektirir. Kentsel dönüșüm projeleri, çöküntü alanları haline gelmiș kentsel alanlarda ekonomik canlanmayı sağlayarak kentsel refah ve yașam kalitesini artırmayı amaçlar.

Kentsel dönüșüm ihtiyacı, afet riski bulunan alanlarda olası zararları azaltmak ya da afet sonrası gerçekleșen yıkımı ortadan kaldırmak amacıyla da ortaya çıkabilir. Kentsel rantın çok düșmüș olması, bu alanların tekrar ele alınmasını çok karlı hale getirebildiği gibi; bu alanlardaki sosyal risklerin fazlaca artmıș olması, bu alanların yenilenmesini bir zorunluluk haline de getirebilir. Ayrıca kentlerde var olan kültürel alanların fiziki olarak korunması ve kentsel dokunun mevcut ekonomik yașama ișlevsel olarak adapte edilmesi isteği de kentsel dönüșüm ihtiyacını gündeme getirmektedir. 
Az gelișmiș/gelișmekte olan ülkelerdeki denetimsiz, kontrolsüz ve hızlı büyüme anlayıșı kentsel, çevresel ve sosyal sorunları derinleștirmektedir. Sanayileșmenin farklı kentlerde farklı düzeylerde yaşanıyor olması, kentlerin farklı tarihi, kültürel, coğrafi özelliklere sahip olması ve afet riskleri ya da nüfus yoğunluklarının farklı olması gibi etkenler, kentsel dönüșümle ilgili uygulamaların değișiklik göstermesine neden olmaktadır. Bu nedenle kentsel dönüşüm uygulamalarının, dönüşümü amaçlanan alanlarda duyulan ihtiyaca göre çeşitli şekillerde adlandırıldıkları görülmektedir. Örneğin Roberts ve Sykes'nn (2000: 14) kentsel dönüşümün gelişimiyle ilgili yaptıkları dönemsel sınıflandırmada 1950'ler yeniden inșa, 1960 'lar kentsel canlandırma, 1970'ler kentsel yenileme, 1980'ler yeniden geliștirme, 1990'lar yeniden canlandırma uygulamalarının öne çıktığı dönemler olarak özetlenmektedir. Batı ülkelerinde özellikle 2.Dünya Savașı sonrası olușan yıkıma kentsel yenileme ve yeniden yapılandırma uygulamaları ile müdahale edildiği; sonraki dönemlerde ise kentsel canlandırma, iyileștirme, sağlıklaștırma ve koruma gibi araçların öne çıkłığı görülmektedir.

Sosyal, ekonomik ve politik değișimler, aktörlerin kentsel dönüșümdeki rol ve sorumluluk derecelerini de değiștirmiștir. Kentsel dönüșüm, 1960'lara kadar genelde devlet eliyle toptan bir șekilde gerçekleștirilmiștir. Bu tarihten sonra gayrimenkul temelli olsa da kamu- özel ortaklıkları yaygınlașmıștır. 1990'lardan itibaren toplumun yeniden hatırlandığı ve ortaklık modellerinin çeșitlendiği dönüșüm çalıșmaları görülmektedir (Görgülü vd., 2006: 17).

\section{Türkiye'de Kentsel Dönüșümün Gerekliliği ve Gelișimi}

Avrupa'da 1990'lı yıllarda kentlerin toplam nüfusun yaklașık yüzde 90'ını barındırması ve ekonomik çıkıının büyük ölçüde kentler tarafından sağlanması olgusu, Türkiye için büyük ölçüde 2000'li yıllardan sonrası için geçerlidir. Kentlerin ekonomik gücünün geliștirilmesi, ülkenin bir bütün olarak rekabetçi performansı için kritik öneme sahiptir. Kentlerin oynamaya bașladığı bu kritik ekonomik rol, diğer ülkelerde olduğu gibi Türkiye'de de etkili bir kentsel yenilenmeye duyulan ihtiyacı yansıtmaktadır.

Türkiye'nin hızlı kentleșme serüveni 1950'lerde bașlamıștır. Bu süreçte yeni kent merkezleri ortaya çıkmıș; bu merkezlerdeki kentsel rantın artması, çok katlı yapıların inșa edilmesine ve yerleșime açılmaması uygun olan yeșil alanlar ve tarım topraklarının konutlarla kaplanmasına neden olmuștur. Bu plansız dönüșüm süreci, kentlerin doğal, tarihi ve 
kültürel çevreyi ve afet risklerini göz ardı ederek büyümesine neden olmuștur. 1980 sonrası kent çevresine eklemlenen sanayi bölgeleri, devlet kurumları ve üniversiteler gibi olușumlarla büyümeye devam etmiștir (Genç, 2008: 117).

1970'lerden itibaren Toplumsal Belediyecilik anlayıșı doğrultusunda gecekondu mahallelerine altyapı hizmetlerinin götürülmesi, her ne kadar bu alanların görece yașam standartlarını arttırmıș olsa da temel amaç, kentin dönüștürülmesinden ziyade çarpık kentleșmenin yarattığı bu alanlardaki sorunların yine çarpık bir șekilde ötelenmesi olarak değerlendirilebilir. Zira daha sonraki süreçte bu tek katı ruhsatsız alanlar, çok katlı, yine ruhsatsız yapılan ama sonradan ruhsat verilen alanlara dönüșmüștür.

Kentsel dönüșümün öncesi ve sonrası kıyaslandığında önemli ölçüde farklı ve olumlu bir değișimin gözlenmesi gerekir. Bu açıdan gecekondu ya da ruhsatsız konut alanlarının fiziksel planlama yoluyla düzenli konut alanlarına dönüștürülmesinin ilk ve sınırlı̈̈rnekleri 1970'lere dayanmakla birlikte, uygulamada kentsel dönüșümün planlamada bir araç olarak kullanılmaya bașlanması 1980'li yıllardan sonraya denk gelmektedir. Bu dönemde serbest piyasa ekonomisine geçișle birlikte çıkarılan gecekondu affı yasaları, kent çeperlerindeki gecekondular için uygulamaya konan ıslah imar planları ya da kent merkezlerindeki alanların özel projelerle dönüștürülmesi gibi uygulamalarla kentsel dönüșüm süreci bașlamıștır (Sönmez, 2006: 121).

1980 sonrası konut sorununa yönelik çözümler, kooperatif örgütlerinin kurulması, TOKi'nin ve Türkiye Emlak Bankası'nın desteklediği toplu konut uygulamalarıdır. 1983- 1988 arasında çıkarılan beș af yasası ile gecekondu alanlarındaki mülkiyet sorununun çözülmesi ve gecekonduların apartman türü konutlara dönüștürülmesi amaçlamıștır. Ancak gerçekleșecek dönüșüm, tamamen piyasa koșullarına bırakılmıș; önce yasadıșı konut alanlarının yasallașması, sonra planlı gelișim alanları olușturulması hedeflenmiștir (Ataöv \& Osmay, 2007: 66). Bu dönemdeki en önemli yasal düzenlemeler, 3030 Sayılı Büyükșehir Belediye Kanunu (1984), 3194 sayılı Imar Kanunu (1985) ve 2985 sayılı Toplu Konut Kanunu (1984)'dur. Bu dönem, kentlerdeki gecekondu sorununun yasal önlemlerle çözülmeye çalıșıldığı, belediyelerin kent planlamasında söz sahibi haline geldiği, merkezi yönetimin de konut sıkıntısına müdahale etmeye ve konut piyasasını yönlendirmeye bașladığı bir dönemdir. Kent- 
sel dönüșümün doğrudan yasalarda yer alması, 2000'li yılların sonrasına denk gelmektedir.

Türkiye'de kentsel dönüșüm stratejisi olarak ağırlığın kentsel yenileme uygulamalarında olduğu ifade edilebilir (Ataöv ve Osmay, 2007: 58). Eski mevzuata göre inșa edilen dayanıksız ve sağlıksız bina sayısının fazla olması, bașta deprem olmak üzere afet riskinin çok yüksek olması, mevzuattaki düzenlemelere rağmen kaçak yapılașmanın devam etmesi gibi nedenler, fiziki yenilemenin ön plana alınmasında etkilidir. Türkiye'de kentsel dönüșüm projelerinin önceliğinin doğal afet risklerine yönelik alanlara, çöküntü bölgelerine ve gecekondu alanlarına yönelik olması nedeniyle toplumsal ve ekonomik yönlerden iyileștirme ve geliștirme projeleri genelde ikinci planda kalmaktadır (Ayhan, 2013: 83). Ankara'da Beypazarı ve Hamamönü, Antalya'da Kaleiçi örneklerinde olduğu gibi özgün niteliğini kaybetmemiș alanların yeniden eski haline getirilmesi-sağlıklaștırma uygulamaları olmakla birlikte; İstanbul Sulukule örneğindeki gibi kentsel yenileme yapılan birçok alanda hem kentsel hem de sosyal dokunun yeterince korunamadığı söylenebilir.

Tarihi veya özgün niteliği olan ve zaman içinde çöküntü sürecine girmiș olan semtlerin soylulaștırma (gentrification) yoluyla dönüștürülmesi uygulamaları da Türkiye' de kentsel dönüșüm sürecinde yer almaktadır (Genç, 2008: 122). Soylulaștırma, orta ve orta üstü gelir gruplarının, fiziksel müdahale yolu ile yenilenen alt gelir grubu konut alanlarına yerleșmesi olarak tanımlanabilir (Sönmez, 2006: 122). Soylulaștırma sonucu alandaki konut stokunun artmasının yanı sıra gerçekleșen fiziki ve sosyal değișim, tüm kent ve bölge düzeyinde etkili olmaktadır (Kennedy ve Leonard, 2001: 5). Ancak bu yer değișimin temel özelliği, o bölgede yașamaya devam etmek isteseler de artan kiralar ve emlak vergileri gibi nedenlerle asıl sahiplerinin tașınmak zorunda kalmaları yani gönüllülük esasına dayanmamasıdır. Merkezi iș alanlarının dönüșümü, sit alanlarının korunması ve turizm amaçlı dönüșümler de sayıca az olmakla birlikte Türkiye'de kentsel dönüșüm uygulamaları arasında yer almaktadır.

2011 Nüfus ve Konut Araștırması sonuçlarına göre, Türkiye'de toplam 19 milyon 482 bin hanehalkı vardır. Bu hanehalklarından 19 milyon 454 bini $(y u ̈ z d e ~ 99,9)$ konut niteliğindeki adreslerde ikamet etmektedir. 
Tablo-1: Hanehalklarının Bina İnșa Yılına Göre Dağılımı

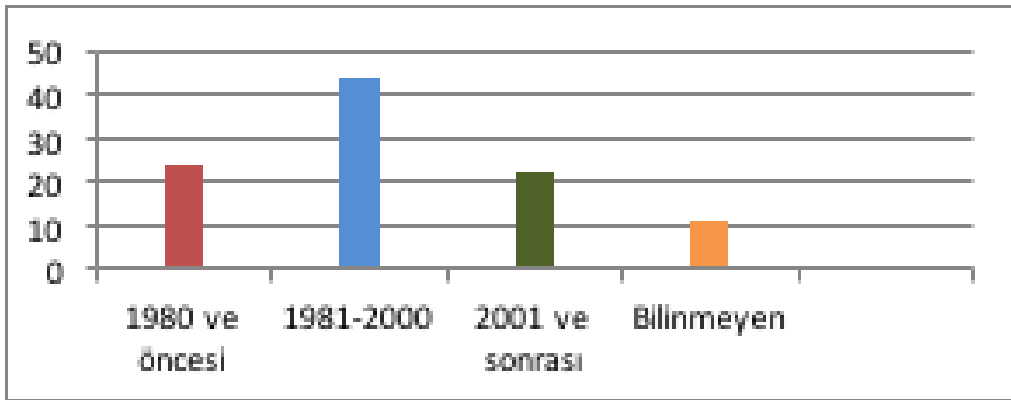

Kaynak: TÜiK, 2011 Konut ve Nüfus Araștırması.

Hanehalklarının ikamet ettikleri konutların bulunduğu binaların yüzde 23,4'ü 1980 ve öncesinde, yüzde 43,5'i 1981-2000 yılları arasında, yüzde 21,8'i ise 2001 ve sonraki yıllarda inșa edilmiștir. Konutların yaklașık 5 milyonu 2001 yılı ve sonrası inșa edildiği için depreme uygun güvenli konutlar olarak öncekilere göre kısmen iyi durumda kabul edilmektedir. Kalan yaklașık 14 milyon yapının elden geçmesi gerektiği ifade edilmekte ve bunların yaklașık yarısı da riskli olarak değerlendirilmektedir (Makas, 2012: 34). Riskli olduğu ifade edilen yaklașık 7 milyon yapının bir kısmının yıkılıp yeniden yapılması ve bir kısmının güçlendirilmesi için 100 ila 400 milyar dolar arası olacağı tahmin edilen bir finansman ihtiyacı bulunmaktadır.

Tablo-2: Hanehalklarının Konuttaki Mülkiyet Durumuna Göre Dağılımları

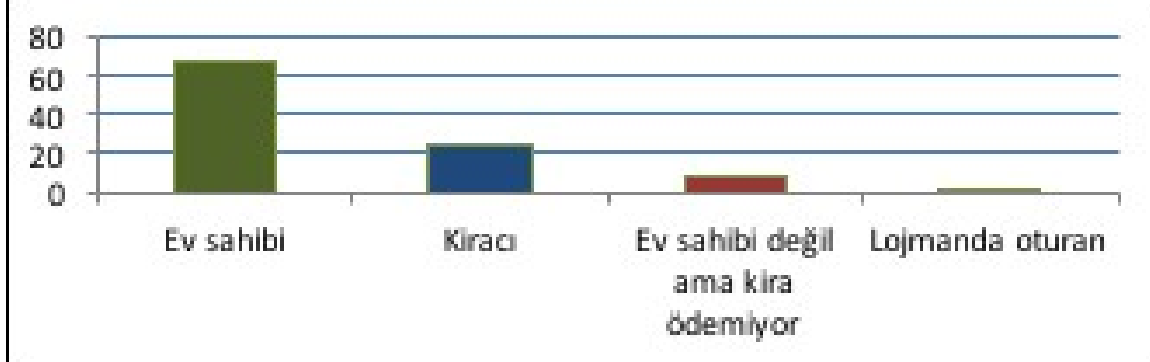

Kaynak: TÜIK, 2011 Konut ve Nüfus Araștırması.

Türkiye'de ikamet ettikleri konutta kiracı olanların oranı yüzde 23,8'dir. Hanehalklarının yüzde 67,3'ü ikamet ettikleri konutun sahibidir. Hanehalkının yüksek oranda kendi konutuna sahip olması, kentsel dönüșüm açısından tarafların belirlenmesi ve gerekli anlașmaların sağlanmasını kolaylaștırıcı bir unsur olarak düșünülebilir. 
Oturdukları konutun sahibi olmayan ancak kira ödemeyen hanehalklarının oranı ise yüzde 7,3'tür. Oturdukları konutta kiracı olan hanehalklarının oransal olarak en yüksek olduğu iller İstanbul, Kocaeli, Ankara, Eskișehir, İzmir, Antalya ve Gaziantep'tir. Kiracı olarak belirlenen hanehalklarının çoğunun dönüșüme en çok ihtiyaç duyulan büyükșehirlerde bulunmaları, dönüșüm uygulamalarında bu kesimin de göz önünde bulundurulması gerektiğini hatırlatmaktadır. Bu açıdan kentsel dönüșümden etkilenecek kiracıların konut sahibi olabilmesini ya da en azından uygun kira düzeyleriyle konuta ulașabilmelerini sağlayabilecek politikaların izlenmesi uygun olacaktır.

Tablo-3: Türkiye'de Konut Satıș Sayıları (2013-2017)

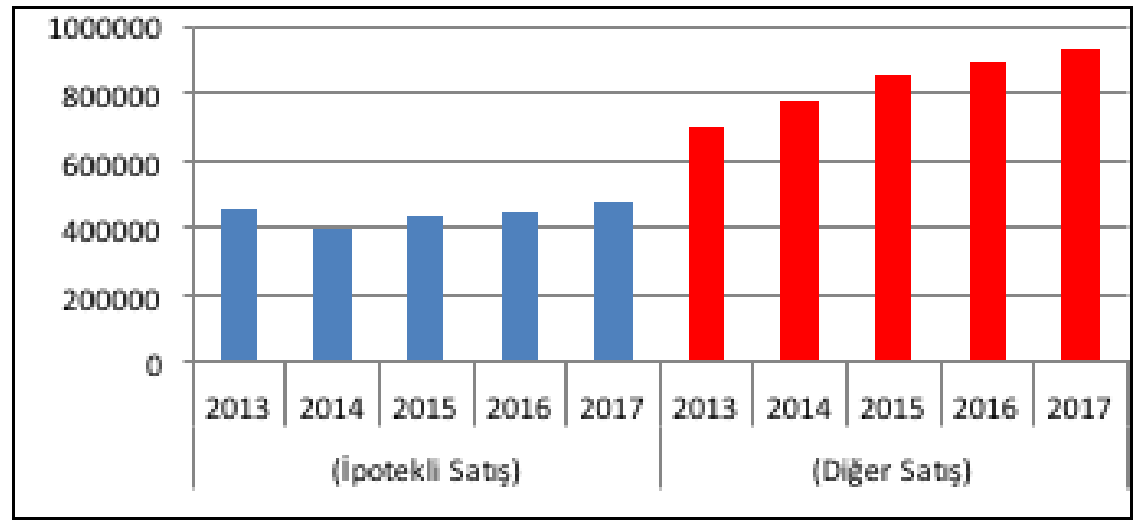

Kaynak: TÜiK konut verileri doğrultusunda hazırlanmıștır.

Tablo-3'de görüldüğü gibi konut satıșlarının yaklașık üçte biri ipotekli konut finansmanı ile finanse edilmektedir. Konuyla ilgili veri olmamakla birlikte Türkiye'de artan konut satıșlarının bir bölümünün kentsel dönüșümle ilgili olduğu varsayılabilir. Belirtilen varsayım doğru kabul edildiğinde kentsel dönüșüm, konut kredisi hacminin artmasında da etkili olacaktır. Üretici açısından da kullanılan inșaat kredisi hacmindeki artıșın bir bölümü kentsel dönüșüme bağlanabilir. Bu doğrultuda kredi hacmi ile ekonomik büyüme arasındaki doğrusal ilișki nedeniyle, kentsel dönüșümün ekonomik büyüme ve istihdam üzerinde olumlu etkileri olduğu söylenebilir (Coșkun, 2016). Konut, temel bir ihtiyaç olması ve topluma yönelik pozitif dıșsallık özelliği nedeniyle çeșitli teșviklerle ve TOKI uygulamalarıyla devlet tarafından desteklenmektedir. Desteklerin yeterliliği ayrı bir inceleme konusu olmakla birlikte kentsel dönüșüm sürecinde sağlanan faiz desteği, vergi indirimleri, kira yardımları gibi uy- 
gulamalar, konut politikaları açısından olumlu bir katkı sağlayacaktır. Zaten kentsel dönüșüm uygulamalarının kendisi, kentsel alandaki arsa kıtlığı sorununun așılmasına ve konut arzının artmasına neden olmaktadır. Kentsel dönüșümün yarattığı spekülatif etki nedeniyle arz artıșının fiyatlarda așağı yönlü bir etki yarattığını söylemek henüz mümkün olmasa da (Coșkun, 2016) artan konut arzı, özellikle büyükșehirlerde kira fiyatlarının düșmesine ve kiralık konuta ulașma imkânını arttıracaktır.

\section{Kentsel Dönüșümde Kamu Müdahalesi}

Uluslararası rekabette kentlerin öneminin artması sonucu kentler, turizm, ileri teknoloji, tarihi ve kültürel yapı gibi kendilerine has özellikleriyle bağlantılı kentsel stratejiler geliștirmektedirler. Bu doğrultuda kentsel dönüșümle ilgili önemli yeniliklerden biri, 1980'li yıllardan sonra kamunun dönüșüm için tüm kaynaklarını ayırmak yerine, özel sektör ile ortaklıklar kurması ve özellikle 1990'lı yıllarda yerel halk ve gönüllü kurulușları kapsayan çok aktörlü bir dönüșüme gidilmesi olmuștur. Daha geniș tabanlı bir ortaklık yapısına geçiș, mülkiyet temelli bir kentsel dönüșümden tüm toplumun faydasına odaklanan sosyal yönleri de olan bir kentsel dönüșüm anlayıșına geçișle bağlantılıdır (Adair vd., 2000: 147).

Yerel destek, projelerin sürdürülebilirliği ve bașarısı açısından; kamu, sorunlu alanların tespit edilmesi ve planlanması, örgüt deneyimi, kaynak sağlama, risk paylașımı ve hukuki güvence sağlaması açısından; özel sektör ise kaynak sağlama, uzmanlık ve yenilikçilik özellikleri açısından ön plana çıkmaktadır. Bu açıdan tarafların bir araya gelmelerini sağlayacak düzenlemeler, dönüșümden elde edilmek istenen sonuçların gerçekleștirilmesi açısından önemlidir. Bu açıdan her yönüyle topluma faydalı olabilecek bir kentsel dönüșümde așılması gereken önemli engellerden biri, finansman sorunudur. Bu açıdan özel sektör finansmanını kentsel dönüșüm sürecine çekecek etkin mekanizmaların, özellikle de özel sektörün yatırımına katkıda bulunacak koșulların neler olduğunun değerlendirilmesi gerekmektedir. 
Tablo-4: ABC Modeline Göre Maliyetler ve Değerler

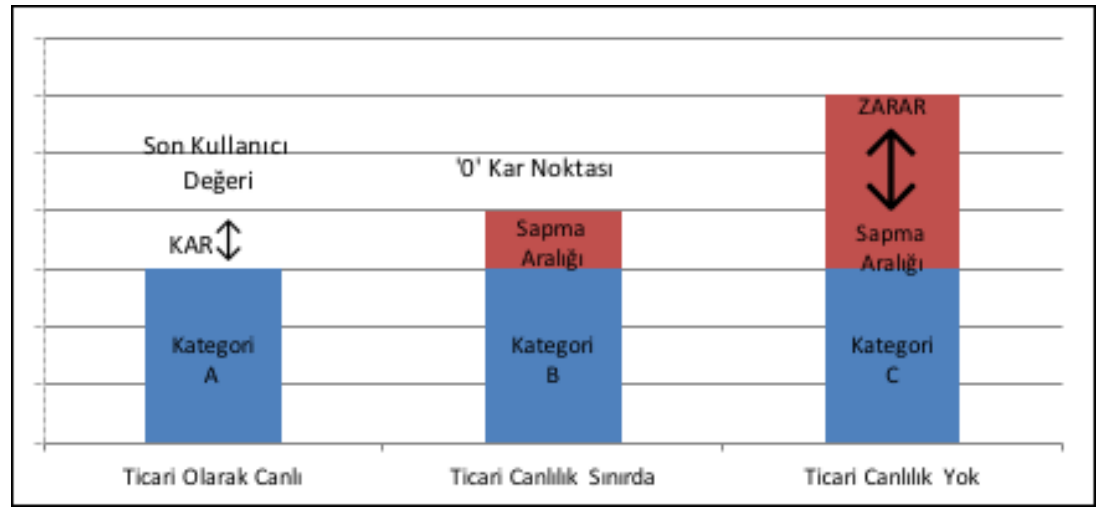

Kaynak: Concerted Action on Brownfield and Economic Regeneration Network (Cabernet), 2005:4; Sahin, 2012: 28.

Cabernet'in eski sanayi alanlarının dönüșümüyle ilgili ortaya koyduğu $A B C$ modeline göre arsanın dönüșümünden elde edilecek gelir, tüm maliyetleri karșılamanın yanı sıra belirli bir kar payı bırakıyorsa, kendi bașına dönüșebilen bu alanlarda finansal açıdan dönüșüm, problemsiz bir șekilde gerçekleșmektedir (Șahin, 2012: 28). Piyasa, bu alanları kamunun yardımı olmaksızın dönüștürebilir.

Ancak piyasa bașarısızlığı durumunda toplumsal ihtiyaç alanlarında toplanmıș B ve C bölgelerindeki boș, kullanılmayan ya da kötü durumdaki alanlarla bașa çıkmak için yürütülecek kamusal politikalar, kentsel dönüșümün haklı ve önemli bir bileșenidir. Yeniden geliștirme maliyetleri, beklenen maliyetlerden düșükse kamu kesiminin maliyetlerin azaltılması ya da elde edilmesi muhtemel piyasa değerlerinin yükseltilmesi șeklinde vereceği desteklerle birlikte özellikle B bölgesindeki alanların dönüșümü, özel kesim tarafından öne alınabilir (Cabernet, 2005:5).

Özel sektöre maliyet-değer farkının giderilmesi yani açı̆̆ın finansmanı amacıyla isteğe bağlı hibe destekleri verilebilir. Böylece kamu yararı ile doğru orantılı olarak ticari açıdan uygun bulunan projelere yardım edilmesi mümkün olabilir. Kamunun özel kesime verebileceği desteklerden bir diğeri vergi teșvikleridir. İsteğe bağlı destekler yerine daha genel yapıdaki vergi teșviklerinin verilmesi durumunda ihtiyaç duyulup duyulmadığı fark etmeksizin elde edilecek fayda ve destekten her proje faydalanabilecektir. Düșük faizli krediler, alt yapının iyileștirilmesi ya da alanların planlama durumlarının değiștirilmesi șeklinde o bölgeye yönelik girișimler ya da mevcut sahibinden zorunlu olarak toprak satın 
alınması yoluyla arazinin birleștirilmesi șeklinde diğer destekler de verilebilir (Cabernet, 2005:6). Bu destekler, kentsel yenileme alanında özel sektördeki rekabet ve yeniliği teșvik etme fırsatı sunar.

Özel sektörün teșvik edilmesi daha zor olan ve öngörülebilir bir gelecekte dönüșüm potansiyeli olmayan C Kategorisindeki alanlar gibi alanlarda ise tüm maliyet ve riskleri alarak devletin ilgili alanın dönüșümünü gerçekleștirmesi mümkündür. Bir bașka ifade ile bu alanlarda devletin özel sektörü devreye sokmaması; diğer alanlarda ise özel sektör ortaklığına bașvurması mantıklı bir seçim olarak değerlendirilebilir.

10. Kalkınma Planı (2014-2018) doğrultusunda hazırlanan Rekabetçiliği ve Sosyal Uyumu Geliștiren Kentsel Dönüșüm Programı Eylem Planı́nda kentsel dönüșümün finansmanının kolaylaștırılması amacıyla üç temel politika belirlenmiștir. Bu politikalar, dönüșüm kaynaklı değer artıșlarından kamunun daha fazla pay alması, yeni finansal araçların geliștirilmesi, dönüșümün değer artıșıyla finanse edilmesinde sorun yașanılan alanlarda finansman imkânının kolaylaștırılmasını sağlayacak bir sistem olușturulmasıdır. Bu politikaların hayata geçirilebilmesi için yapılması öngörülen eylemler;

- Afet riski ve artı değer üretme potansiyeli yüksek alanlar ile projeden yararlanacak kiși sayıları göz önünde tutularak kentsel dönüșümde öncelikli alanların belirlenmesi,

- İmar planı değișiklikleri sonucu ortaya çıkacak artı değerden kamunun daha fazla pay almasını sağlayacak düzenlemelerin yapılması,

- Gayrimenkul Sertifikası Modelinin geliștirilmesi,

- Kentsel dönüșüm projelerinde Sukuk ihracının kolaylaștırılması ve yabancı finans kurulușlarının gayrimenkul edinimlerinde karșılaștıkları güçlüklerin kaldırılması,

- Dönüșüm Özel Hesabının öncelikle artı değer üretmeyen ve afet riski yüksek alanlardaki dönüșüm projelerinin desteklenmesi amacıyla verilen desteklerde bazı avantajlar ve faiz desteği sağlanması gibi farklılașmaya gidilmesi olarak belirlenmiștir. 


\subsection{Hukuki Düzenlemeler Kapsamında Kamusal Kaynaklardan Sağlanan Finansmanla Gerçekleștirilen Kentsel Dönüșüm}

Büyük finansal kaynaklara olan ihtiyaç nedeniyle kamu, kentsel toprakları yenilemek için gerekli kaynakları sağlayabilirse de kentsel dönüșüm projeleri nadiren yalnızca kamu tarafından uygulanmaktadır. Yeterince faydalanılamayan kentsel arazilerin yenilenmesinde sürdürülebilirliği sağlamak için toplumun ve özel sektörün katılımı belirleyici bir faktördür. Kentsel yenileme girișimleri, ișletmeler için yeni fırsatlar yaratırken; yerel ekonomik kalkınma yoluyla daha önce verimsiz olan alanlarda toplum için yeni gelir getiren ve dolayısıyla devlet için de vergi üreten faaliyetleri artırabilir (Amirtahmasebi vd, 2016: xvi).

2011 yılında Van'da meydana gelen deprem sonrasında yașanan can kayıpları ve sosyo-ekonomik problemler ile devletin beklenmedik bir anda karșı karșıya kaldığı büyük mali külfetler, afet riski alında bulunan alanların yeniden düzenlenmesi ihtiyacını bir kez daha ortaya çıkarmıștır. Bu amaçla 2012 yılında 6306 sayılı Afet Riski Altındaki Alanların Dönüștürülmesi Hakkında Kanun çıkarılmıștır. Kanun ile sadece afet bölgesindeki yapıların değil; tüm riskli yapıların malikleri ile anlașılarak yıkılıp, yeniden yerleșime uygun hale getirilmesi hedeflenmektedir. Bu kanun, afet riski alındaki alanlar ile bu alanlar dıșındaki riskli yapıların bulunduğu arsa ve arazilerde iyileștirme, tasfiye ve yenilemelere dair usul ve esasları belirlemek amacıyla çıkarılmıștır. Kanun kapsamında uygulamada bulunacak olan belediyeler, yatırıma ilișkin yıllık bütçelerinin yüzde 5'i ile 2464 sayılı Belediye Gelirleri Kanunu yarınca tahsil edilen harç gelirlerinin yüzde 50'sini öngörülen uygulamalara ayırmak zorundadır.

6306 sayılı Kanuna dayanılarak hazırlan 2017 tarihli Dönüșüm Projeleri Özel Hesabı Yönetmeliği ile dönüșüm projeleri özel hesabı gelirlerinin elde edilmesi, tahsili ve takibi ile bu hesaba bütçeden aktarılan tutarların dönüșüm faaliyetleri kapsamında yürütülecek hibe veya borç verme programlarında kullanılmasına ilișkin esaslar belirlenmiștir. Yönetmelikte sayılan gelirler, kentsel dönüșüm uygulamalarında kullanılmak üzere Merkezi Yönetim Bütçe Kanununa ekli (B) cetvelinde "Afet Riski Alındaki Alanların Dönüșüm Gelirleri" adı alında özel gelir olarak öngörülmüștür. Yönetmelikte sayılan bu gelirler;

- Çevre katkı payı ve idari para cezası olarak tahsil edilerek genel bütçeye gelir kaydedilecek tutarın yüzde 50'si; 
- Hazine adına orman dıșına çıkarılan yerlerin satıșından elde edilen gelirlerin yüzde 90'nını geçmemek üzere Bakanlar Kurulu kararı ile belirlenen orana tekabül eden tutar;

- iller Bankası A.Ș'nin Hazine gelirleri ve faiz gelirleri dıșındaki banka faaliyetleri ile kendi kanununda belirtilmiș bazı faaliyetlerinden elde edeceği kârın yüzde 50'sidir.

Maddede yer alan yüzde 90'ı geçememek üzere bir üst sınır belirlenmesi yerine bu hesaba daha fazla kaynak aktarılabilmesi için alt sınırın belirlenmesi daha uygun görünmektedir. Bunun nedeni, 2013 yılı bütçesinde söz konusu satıștan 4.081.631.000 TL gelir sağlanacağı öngörülmesine karșılık, dönüșüm hesabına belirtilen diğer kaynaklardan elde edilen gelirler de dâhil olmak üzere, toplam 731.574.000 TL özel gelir öngörülmüștür (Solmaz, 2013: 119). Yani diğer kaynaklardan hiç gelir elde edilemediğini varsayarak hesaplansa bile elde edilen gelirin yüzde 18'inin dönüșüm hesabına aktarıldığı görülmektedir. Diğer gelirleri eklediğimizde oran daha da düșecektir. Çevre ve Șehircilik Bakanlığı, Kanun kapsamındaki uygulamalarda kullanılmak üzere özel hesaptan TOKI, belediyeler, il özel idareleri ve iller Bankası A.Ș'ye kaynak aktarabilir. Yönetmelikte ilgili özel hesaptan yapılacak harcamalar șU șekilde belirlenmiștir;

- Dönüșüm hizmetlerine ait harcamalar;

- Gerekli tașınmazların satın alınması ve kamulaștırılması ile ilgili harcamalar;

- Riskli alanların belirlenmesi, riskli yapıların tespit, tahliye ve yıktırma iș ve ișlemlerinin gerektirdiği harcamalar;

- Tahliye edilen yapıların maliklerine yapılan kira ödemeleri;

- Konutunu ve ișyerini kendi imkânları ile yapmak veya edinmek isteyenlere verilen konut ve ișyeri kredileri;

- Riskli alanda yer alan veya riskli olduğu tespit edilen yapılar için verilecek yıkım kredileri, güçlendirme kredileri ve hak sahiplerince bankalardan kullanılacak kredilere verilebilecek faiz desteği ödemeleridir.

Diğer bir finansman kaynağı, 1983 tarih ve 2863 sayılı Kültür ve Tabiat Varlıklarını Koruma Kanunu'nda belirtilmiștir. Buna göre belediyelerin ve il özel idarelerinin görev alanlarında kalan kültür varlıklarının korunması ve değerlendirilmesi amacıyla hazırlanan projeler kapsamın- 
da kamulaștırma, projelendirme, plânlama ve uygulama konularında kullanılmak üzere tahakkuk eden emlak vergisinin yüzde 10'u nispetinde Tașınmaz Kültür Varlıklarının Korunmasına Katkı Payı tahakkuk ettirilecektir. Bu tutar, ilgili belediye tarafından emlak vergisi ile birlikte tahsil edilecektir.

Türkiye' de yerel yönetimlerle birlikte Bașbakanlık Toplu Konut İdaresi Bașkanlığı́nın (TOKI) uygulanan dönüșüm projelerinde önemli bir yeri ve etkisi bulunmaktadır. TOKI'nin kanunda sayılan konut uygulamaları için belirlenen tahvil ve her türlü menkul kıymet çıkarmak, yurtdıșından kredi almak, bankalara kredi vermek, dönüșüm projelerini kredilendirmek ve gerektiğinde bu kredilere faiz sübvansiyonu sağlamak, kar amaçlı projeler yapmak gibi görevleri bulunmaktadır. Bu görevlere bakıldığında TOKI'nin bir finans kurulușu ișlevine sahip olduğu görülmektedir.

Dönüșümün uygulama yapılacak tașınmazın sahipleri tarafından gerçekleștirilmesi mümkündür. Öneğin; 5366 sayılı Yıpranan Tarihi ve Kültürel Tașınmaz Varlıklarının Yenilenerek Korunması ve Yașatılarak Kullanılması Hakkında Kanuna göre, yenileme alanı içerisinde kalan parselin sahibinin projeye bağlı kalmak ve il özel idaresi ve belediyenin belirleyeceği amaçta kullanılmak kaydıyla yenileme uygulamasını bizzat gerçekleștirebileceği ifade edilmektedir. 6306 sayılı Kanunda üzerinde bina yıkılarak arsa hâline gelen tașınmazlarda parsellerin malikleri tarafından değerlendirilmesinin esas olduğu ifade edilmiștir. Afet Riski Alındaki Alanların Dönüștürülmesi Hakkında Kanunun Uygulama Yönetmeliğinde, riskli alanlarda ve riskli yapılarda kanun kapsamında öncelikle maliklerce uygulama yapılmasının esas olduğu belirtilmiștir. Ancak özel hukuk kișilerinin bir ortaklık kurmadan ve kamu müdahalesi olmadan bir kentsel dönüșüm faaliyeti gerçekleștirmesi oldukça zordur. Bu doğrultuda özel hukuk kișileri, yapı kooperatifleri kurarak da kentsel dönüșüm faaliyeti gerçekleștirebilirler (Hacribrahimoğlu, 2013: 97). Fiziki dönüșümlerde bu tarz tekil uygulamalara imkân verilmekle birlikte, kentsel dönüșümün gerçekleștirildiği alanın sosyal, demografik, ekonomik bir bütün halinde ele alınması gereği nedeniyle kentsel dönüșüm alanının belirlenmesi, planlanması veya denetlenmesi gibi șekillerde kamu müdahalesine ihtiyaç duyulmaktadır. 


\subsection{Kamu- Özel Kesim Ortaklıklarının Kullanılması}

Kentsel dönüșüm, uzun vadeli, karmașık ve çoğunlukla parçalı bir süreç olduğundan bașarılı olmak için ortak vizyon ve hedeflere sahip birimlerin ortak çalıșmasını gerektirir. Bu açıdan kamu- özel kesim ortaklıkları, kentsel dönüșümde kullanılabilecek önemli bir araçtır. Jung vd. (2015), kentsel dönüșümde paydașların ișbirliğini, paydaș teorisi kapsamında ele almıșlardır. Ortak bir soruna çözüm sağlamak istendiğinde çeșitli gruplar ișbirliğine giderek uzun vadede karșıt paydașlar arasındaki muhtemel çatıșmaları çözme maliyetinden kaçınmak gibi çeșitli faydalar sağlamak amacıyla ișbirliği yapmaktadır. Bu nedenle etkinlik ve güveni sağlamak açısından meșru çıkarları olan kilit paydașları belirlemek önemlidir. Kamu- özel kesim ortaklıkları, kamu projelerini gerçekleștirmek amacıyla özel sektörün projeye dahil edilmesi ile özel sektörün proje geliștirme, inșa, bakım-onarım, ișletme ve finansman așamalarında projeye katkı sağlamasıyla olușturulan ortaklıklardır. Bu ortaklıklardaki temel gaye, kamu hizmetlerinin daha nitelikli ve az maliyetle özel sektör aracılığıyla sunulmasıdır.

Bazı yazarlara göre kamu- özel kesim ortaklıkları, diğer amaç ve stratejileri gölgelemek amacıyla tasarlanan bir kelime oyunudur. Bu amaçlardan biri, özelleștirme ve diğeri de kamu kurulușlarının kendi katlandığı maliyetlerle özel sektörün hizmet sunmasını sağlaması olabilir. İhale ve özelleștirme kavramları daha hızlı bir muhalefet yaratmakta; alternatif dağıtım sistemleri ya da kamu-özel kesim ortaklığı gibi ifadeler ise daha fazla kiși ve kurumu kavram üzerinde tartıșmaya ve düșünmeye davet etmektedir. Bu da, özel kurulușların kamu hizmeti sunumunda pazar payı elde etmesini mümkün kılmaktadır (Hodge ve Greve, 2007: 547). Örgütsel ve mali bir düzenleme olarak kamu özel kesim ortaklıklarını ele alan diğer yazarlar için kamu- özel kesim ortaklıkları, ihale yöntemi ve özelleștirme yöntemlerinin bașlıca alternatiflerinden biridir. Buna göre kamu ve özel sektör, sahip oldukları nitelikleri birleștirerek risk, kaynak ve maliyet paylașımı açısından kendilerine fayda yaratmaktadır.

Hodge ve Greve (2007: 547), kamu- özel kesim ortaklıklarının kapsadığı temel düzenlemeleri ortak üretim ve risk paylașımı için kurumsal ișbirliği; uzun vadeli yasal sözleșmelerde çıtıların sıkı șekilde belirlendiği uzun vadeli altyapı sözleșmeleri; paydaș ilișkilerinin gevșek olduğu vurgulanan kamusal politika ağları; ortaklık sembolizmi içinde kültürel değișim için benimsenen sivil toplumun gelișimi; kentsel yenileme ve șehir merkezinde ekonomik kalkınma olarak belirtmektedir. Bu kamu 
özel kesim ortaklıkları gruplarından her biri uzun vadeli olma, altyapı kararlarında daha büyük bir potansiyel role sahip olma, daha büyük finansal akımların varlığı ve risklerin ortaklığın her iki tarafına da kaydırılmasına yönelik daha büyük bir kapasitenin olması gibi geleneksel sözleșme düzenlemelerinden farklı etkilere sahiptir.

Yerel kültür turizmini teșvik etmek için kentsel dönüșüm projelerinde festival ve etkinlikler bașlatan șehirler giderek artmaktadır. Bu festival ve etkinlikler yanında kentlerin cazibe merkezleri haline gelmesi için yapılan birçok uygulama, ekonomik fayda sağlama, yerel yașam kalitesini geliștirme ve topluluk sosyal dayanıșması yaratma konusunda yardımcı olmaktadır. Ancak bu uygulamalar, çevresel zararlara neden olma, trafik tıkanıklığını ve belki de kanun uygulama maliyetlerini arttırabilmektedir. Aynı șekilde kentsel dönüșüm de, ekonomik büyüme için yaratıcı bir itici güç olmasına karșın kalkınmadaki sosyal eșitliği azalttığı için eleștirilmektedir. Bu sorunların çözümü olarak çoğu araștırmacı, uzun vadeli fayda elde etmek ve sürdürebilmek amacıyla kamu- özel kesim ortaklıklarının uygulanmasının yanı sıra bu ortaklığa toplum katılımının da eklenmesini önermektedir (Jung vd., 2015: 30).

Türkiye'de de kamu hizmetlerinin nitelik ve nicelik olarak gösterdiği artıș, devlet tarafından yatırımlara ayrılan kaynakların etkin bir șekilde kullanılmasında görülen eksiklikler ve klasik yönetim anlayıșıyla kamu hizmetlerinin istenen kalite ve düzeyde gerçekleștirilememesi nedeniyle alternatif kamu- özel kesim ortaklığı modellerinin uygulanması söz konusu olmuștur. Bu çerçevede 1980'li yıllardan itibaren çeșitli yasal düzenlemeler yapılmıștır. Kamu özel kesim ortaklıkları modelleri, Yapİșlet-Devret, Yap-Kirala-Devret, Yap-Ișlet, Özelleștirme ve İșletme Hakkı Devri ve Imtiyaz Modeli uygulamaları çerçevesinde çıkarılmıș kanunlar ile uygulanmaktadır. (bkz. Kalkınma Bakanlığı, 2015) Mevzuatta kentsel dönüșümü ele alan daha önce bahsedilen diğer kanunlar da kamu özel kesim ortaklıklarının hayata geçirilebilmesine imkân sağlamaktadır. Bu kanunlar, 5393 sayılı Belediye Kanunu, 2863 sayılı Kültür ve Tabiat Varlıklarını Koruma Kanunu, 5366 sayılı Yıpranan Tarihi ve Kültürel Tașınmaz Varlıklarının Yenilenerek Korunması ve Yașatılarak Kullanılması Hakkında Kanun, 2985 sayılı Toplu Konut Kanunu ve 6306 sayılı Afet Riski Alıındaki Alanların Dönüștürülmesi Hakkında Kanun olarak sayılabilir. Sayıca çok, dağınık ve uygulayıcılar için karmașık olan bu mevzuat yapısının bir çerçeve kanun ile düzenlenmesi öngörülmüș olmakla birlikte henüz böyle bir kanun çıkarılmamıștır. 


\subsection{Gayrimenkule Dayalı Sermaye Piyasası Araçlarının Düzenlenmesi}

Kent ölçeğinde uygulanabilir ve sürdürülebilir modellerin geliștirilmesi amacıyla parsel bazında yapılașma yerine, proje bazında yapılașmanın sağlanacağı yerel bazlı planlama anlayıșının kentleșme gündemine girmesi önerilmektedir. Bu doğrultuda projeden etkilenen tüm grupların temsil edileceği yerel bazlı örgütlenmelerin bir araya gelecekleri bir proje yönetim anlayıșının benimsenmesi gerekmektedir (Göksu, 2003). Düșünsel bazda benimsenen bu dönüșümle birlikte yeni finansal yaklașımların uygulamaya geçirilmesi, dönüșüm projelerindeki çeșitliliğe katkı sağlayacaktır.

Daha önce belirtildiği gibi Kentsel Dönüșüm Programı Eylem Planı'nda yer alan öncelikli adımlardan ikisi, sermaye piyasası araçlarından Gayrimenkul Sertifikası modelinin geliștirilmesini ve Sukuk yöntemi uygulamasıyla ilgili engellerin kaldırılmasıdır. Ancak gayrimenkule dayalı çok çeșitli sermaye piyasası araçları bulunmaktadır. Menkul kıymetleștirme (securitization), likit olmayan aktiflerin ihraç edilebilecek ve sermaye piyasalarında alım satım yapılabilecek menkul kıymete dönüștürülmesidir. Kentsel dönüșüm projelerine kaynak sağlama konusunda gayrimenkule dayalı sermaye piyasası araçlarından yararlanmak mümkündür. Konutun duran varlık olarak teminat kalitesinin yüksek olması, menkulleștirme/tahvil/türev piyasalarında ele alınmasının nedenlerinden biridir (Coșkun, 2015: 153). Kentsel dönüșümde yararlanılabilecek finansal araçlar; Gayrimenkul Yatırım Ortaklığı, Gayrimenkul Yatıım Fonu, Kira Sertifikası, İmar Hakkı Transferi Sertifikası, Gayrimenkul Sertifikası, Gecekondu Dönüșüm Sertifikası, İmar Haklarını Toplulaștırma Sertifikası, Konut Sertifikası, Arsa Sertifikası olarak belirlenebilir (Makas, 2012: 28, Göksu, 2003, Coșkun, 2015:216). Bu finansal ürünlerin avantajları kadar riskleri ve dezavantajları bulunabilir; ancak çalıșma, sermaye piyasalarının sahip olduğu hangi araçların kentsel dönüșüm projelerinin finansmanına dâhil edilebileceği ile sınırlıdır.

\subsubsection{Gayrimenkul Yatırım Ortaklığı}

Gayrimenkul yatırım ortaklığı (GYO), gayrimenkullere, gayrimenkule dayalı projelere, gayrimenkule dayalı sermaye piyasası araçlarına ve gayrimenkullere dayalı haklara yatırım yapmak üzere faaliyet gösteren özel bir portföy yönetim șirketidir (SPK, 2007: 4). Portföyündeki gayrimenkullerden kira geliri ve gayrimenkul alım satım kazancı elde ederler. İnșaat ișlerini kendileri üstlenemez, proje yürütemez, ancak inșaatını 
bașka șirketlerin gerçekleștirdiği projelere finansman sağlayabilirler. Konut sektörünün Türkiye ekonomisi içindeki önemi ve konut piyasasında sermaye piyasası araçlarının geliștirilmesi düșüncesi doğrultusunda GYO'nın portföy kazançları, kurumlar vergisinden istisna tutulmuștur ve temettü dağıım zorunlulukları bulunmamaktadır. GYO'lar, aktiflerinde konut, iș/alıșveriș merkezi, kentsel dönüșüm gibi büyük çaplı projelere yer verip, bu projeleri gerçekleștiren inșaat șirketlerine gerekli finansmanı sağlayan kurumlardır. İnșaat projelerinin halka arz edilmesi ve gerekli finansmanın GYO'lann hisse senetlerinin halka arzı karșılığında sağlanması ile ilgili projenin finansman yükü hafiflemektedir (Șarkaya, 2007: 176). İnşaat şirketleri, kendi özkaynaklarının yetmediği durumlarda gerçekleștirecekleri projelerde finansman açıkları nedeniyle borçlanmaya gitmek durumunda kalacaktır. GYO'nın varlığı inșșat șirketlerini borçlanmaları durumunda katlanacakları faiz yükünden kurtarmaktadır. Șirketler, özkaynakları yeterli olsa dahi olușacak özkaynak kullanma maliyeti yükünden GYO'lar aracılığıyla kurtulmuș olmaktadır. GYO'larına yatırım yapan yatırımcılar açısından ise yatırım ortaklığı paylarını borsada satabilmeleri ve paylara ilișkin dalgalanmalardan yararlanmaları mümkün olmaktadır (SPK, 2007: 6).

\subsubsection{Gayrimenkul Yatırım Fonu}

Gayrimenkul Yatırım Fonlarına Illișkin Esaslar Tebliği'ne göre; Gayrimenkul Yatırım Fonu (GYF), nitelikli yatırımcılardan katılma payları karșılığında toplanan paralarla, pay sahipleri hesabına ilgili tebliğde belirtilen varlık ve ișlemlerden olușan porfföyü ișletmek amacıyla portföy yönetim șirketleri ve gayrimenkul portföy yönetim șirketleri tarafından kurulan fonlardır. Nitelikli yatırımcı, nakit mevduatlarının ve sahip olduğu sermaye piyasası araçlarının da dâhil olduğu finansal varlıkların toplamı1.000.000 TL üzerinde olan kișilerdir (Șimșek ve Çakıroğlu, 2017: 90).

Fon portföyündeki tutarlarla gayrimenkul projelerine yatırım yapılabilmektedir. GYF, tașınmaz ve finansal varlıklardan olușan portföyün, yatırım fonlarıyla benzer șekilde ișletilmesine dayanmaktadır (Coșkun, 2015: 221). Gayrimenkul yatırımı, doğrudan gayrimenkul satın alınması, GYO hissesi satın alınması ve GYF katılma belgesi satın alınması șeklinde yapılabilir. Doğrudan gayrimenkul alınması, büyük sermaye gerektirmesi nedeniyle sınırlı bir yatırım imkânı sunmaktadır. GYO hissesi satın alınmasında yatırımdan elde edilen getiri ile gayrimenkul fiyatlarındaki değișimden kaynaklanan getiri arasında borsada ișlem 
görmeleri nedeniyle birtakım sapmalar olușabilmektedir. GYF'lerde, doğrudan gayrimenkul yatırımındaki yüksek sermaye gerekliliği sıkıntısına ve GYO'larda olușan portföy değeri ile hisse fiyatı arasındaki sapmalara rastlanmamaktadır (Özgüç, 2008: 1).

Kentsel dönüșüm uygulamalarında inșaat sektörüne büyük rol düșmekte ancak bu sektöründeki yatırımların büyük meblağlarda olması nedeniyle önemli bir finansman sorunu ortaya çıkmaktadır. Bu finansman açığı, banka kredileri yoluyla sağlandığında katlanılması gereken ek maliyetler doğurmaktadır. Bu sorunun azaltılması için gayrimenkul yatırımlarına kaynak sağlanması amacıyla fonlar olușturulmuștur (Șimșek ve Çakıroğlu, 2017: 92-94). Fonlar sayesinde yatırımcılar, normalde yatırım yapamayacakları büyüklükte ve yüksek getirili gayrimenkullere yatırım yapabilmekte ve gayrimenkullerin değer artıșı ve kira getirisi gibi getirilerinden fon payları oranında kazanç elde etmektedir. Gelirleri kurumlar vergisinden istisna tutulmuș olan GYF'ları, gayrimenkullerin menkul kıymetleștirilmesine imkân sağlamaktadır. Bu sayede, alım satımı zor ve hukuki prosedürü çok olan gayrimenkuller, piyasada kolay bir șekilde ișlem görebilir hale gelmektedir. Fona ait katılım payları borsada ișlem görmediğinden borsadaki hisse senedi fiyat hareketlerinden etkilenmemektedir. Bu avantajları dıșında GYF, yerli ya da yabancı yatırımcıların doğrudan gayrimenkul satın almak yerine bir finansal enstrüman aracılığı ile gayrimenkule yatırım yapmasını sağlamaktadır. Yeni uygulanmaya bașlamakla birlikte fonun hem konut hem de kentsel dönüșüm ekonomisine katkıda bulunması mümkündür.

\subsubsection{Kira Sertifikası}

Faizsiz tahvil olarak da tanımlanan sukuka benzer bir araç olan kira sertifikasına ait esaslar, 2013 tarihli Kira Sertifikaları Tebliği (III61.1)'nde belirlenmiștir. Kira sertifikaları, "varlık kiralama șirketlerince (VKȘ), kendi nam ve sertifika sahiplerinin hesabına ve yararına, satın almak veya kiralamak suretiyle devralınan varlıkların finansmanını sağlamak amacıyla düzenlenen ve sahiplerinin bu varlıklardan elde edilen gelirlerden payları oranında hak sahibi olmalarını sağlayan menkul kıymetlerdir" (Hazine Müsteșarlığı, 2018: 3).

Kısaca devret-kirala-devral yöntemine dayanan kira sertifikaları, Borsa İstanbul'da ișlem görmekte ve ikincil piyasada alınıp satılabilmektedir. Sistemin ișleyiși șu șekilde olmaktadır; kaynak kuruluș olarak adlandırılan ve fon ihtiyacı olan șirket, kira sertifikası ihraç etmesi için bir VKȘ kurar. Kaynak kuruluș, varlığı (örneğin gayrimenkulü) VKȘ'ne 
devreder. VKȘ devraldığı varlığın finansmanını sağlamak üzere kira sertifikası ihraç eder. Söz konusu ihraç ișlemi sonucunda toplanan paralar kaynak kurulușa devir bedeli olarak ödenir. Böylelikle kaynak kurulușun finansman ihtiyacı karșılanmıș olur. VKȘ, devraldığı varlığı, kaynak kurulușa kiralayarak kira geliri elde eder. VKȘ, bu kiralar ile kira sertifikasını elinde bulunduran yatırımcılara dönemsel ödemelerini gerçekleștirir. Kira sertifikasının vadesinin gelmesiyle VKȘ'nin kaynak kurulușa kiraladığı varlık da kaynak kurulușa devredilir. Dolayısıyla VKȘ'nin aktifinde herhangi bir varlık kalmayacağı gibi kira sertifikası ihracıyla yatırımcılara karșı olușan yükümlülüğü de sona ermiș olur. (Köprü, 2013: 62)

Faizsiz yatırımı tercih eden hem yurtiçindeki hem de yurtdıșındaki yatırımcılar için cazip olması nedeniyle yatırımcı kitlesinin genișletilebilmesi ve gelir vergisi stopaj oranın yüzde 10, kurumlar vergisi stopaj oranın yüzde 0 olması nedeniyle yatırımcılar için avantajları olan bu senetler, gayrimenkule dayalı olması nedeniyle kentsel dönüșüm finansmanına katkı sağlayacaktır.

\subsection{4. İmar Hakkı Transferi Sertifikası}

İmar hakkı transferi, "bir parsel üzerindeki imar hakkının tamamen ya da kısmi olarak yasaklanması durumunda bu parsel üzerindeki imar hakkının bir kısmının veya tamamının menkulleștirme yöntemi ile bașka alanlara transfer edilmesidir"(ÇȘB, 2014).

İmar hakkı transferinde arsaların değil imar haklarının alım ve satımı söz konusudur (Göksu, 2003) ve yapılașma hakkı, mülkiyetten ayrı düșünülmektedir. Mülk sahipliğini, tek bir parsele bağlı olmayan bir haklar demeti olarak gören bir yaklașıma dayanmaktadır (Gale, 1977: 82). İmar hakkı transferi ile amaç, imar kısıtlamalarına tabi olan imar haklarının, dönüșümü düșünülen bașka bir alana transfer edilmesi ya da imar hakkının menkul kıymet hakkına dönüșümünün sağlanmasıdır. İmar kısıtlamaları, kent içinde veya çevresinde özellikle tarihi, kültürel, tarımsal ve çevresel öneme sahip yeșil alanların korunması gereği ya da imar planlarında kamusal alan olarak belirlenmiș bölgelerde veya afet riskine sahip alanlarda yer alması nedeniyle ortaya çıkabilir. İmar kısıtlamaları nedeniyle bir bölgede azalmıș olan gelișme potansiyeli, kamusal finansmana bașvurulmaksızın gelișme potansiyeline sahip dönüșüm alanlarına transfer edilebilmektedir. İmar hakkı transferi ile yatırımcıların bu bölgelerdeki imar haklarını satın alabilmesi nedeniyle dönüșüm alanlarına yatırım yapılması potansiyel olarak artmaktadır. Bu açıdan sahip olunan tașınmazın korunması ve bu tașınmazdan maksimum kar 
edebilme amacı ile kentsel dönüșümün/ gelișimin gerçekleștirilmesi gibi amaçları barındıran bir uygulamadır (Mataracı vd, 2017:2).

Uygulamada imar yoğunluğunun azalıılmak istendiği tașınmazın korunacağı bölgeler ile imar hakkının transfer edileceği dönüșmesi istenen bölgelerin belirlenmesi sonrası arsa sahibinin sahip olduğu imar hakkının bașka bir alanda kullanılmasını sağlayacak bir sertifika- İmar Hakkı Transferi Sertifikası (IHTS) verilmektedir. Arsa sahibi, arz talep dengesine göre fiyatı olușan bu sertifikayı ikincil piyasada nakde dönüștürebilmektedir (Makas, 2012: 28). IHTS, dönüșüm alanında gerçekleștirecekleri bir proje için o alandaki imar haklarına ihtiyacı olan yatırımcılar tarafından da piyasada bir menkul değere yatırım yapmak isteyen yatırımcılar tarafından da satın alınabilecektir. İmarla ilgili var olan spekülasyon riski, IHTS'lerle ilgili sıkıntı yașanmasına neden olabilir. Kentsel dönüșüm projelerinde imar hakkı kısıtlamalarından kaynaklanan engellerin așılması ve konut sektörünün finans piyasalarıyla bütünleșmesine katkı sağlaması beklenen imar hakkı transferi ile ilgili mevzuatta bazı düzenlemelere gidilmiș olmakla birlikte Türkiye'de henüz uygulanmamaktadır. Örneğin 2863 sayılı Kanunda değișiklik yapılarak yapılanma hakları kısıtlanmıș tașınmazlara ait mülkiyet veya yapılanma haklarının, imar plânlarındaki aktarım alanlarına devrinde belediyelerin ve valiliklerin yetkili olduğu belirtilmiștir. 2011 yılında çıkarılan Çevre ve Șehircilik Bakanlığı'nın Teșkilat ve Görevleri Hakkında KHK'de (644/648) "İmar Hakkı Transferi" kavramına yer verilmiș; 6306 sayılı Kanun'da da "imar haklarını bașka bir alana aktarma" ifadesi hüküm alınna alınmıștır (Mataracı vd., 2017:5-6).

\subsubsection{Gayrimenkul Sertifikası}

Gayrimenkul sertifikaları, devam eden veya bașlayacak gayrimenkul projelerindeki bağımsız bölümlerin küçük birimlere bölünerek sertifika halinde satılmasına imkân veren ve Borsa İstanbul'da ișlem gören varlığa dayalı bir sermaye piyasası aracıdır. Gayrimenkul sertifikaları, Sermaye Piyasası Kurulu (SPK) tarafından SPK Kanununa dayanılarak hazırlanan 2013 tarih ve VII- 128.2 sayılı Gayrimenkul Sertifikaları Tebliği ile düzenlenmiștir. TOKI tarafından 2017 yılında Park Mavera III projesiyle Gayrimenkul Sertifikası ihraç edilmiș ve borsada ișlem görmeye bașlamıștır. Yeterli sayıda sertifika satın alanlar, proje bitiminde söz konusu bağımsız bölümün sahibi olmaktadır. Yeterli sertifikaya sahip olmayanlar ise muhtemel değer artıșından faydalanmaktadır. Gayrimenkul sertifikası bir dairenin metrekare ile satıșı değildir. 
Bu sertifika TOKI garantörlüğünde inșa edilen bir gayrimenkul projesine ortak olmayı ifade etmektedir. Bir bașka deyișle gayrimenkul sertifikası sahipliği, projenin belli bir bölümüne alınan pay oranında yatırım ortağı olmak anlamına gelmektedir. Ayrıca sertifika sahiplerine projeden daire alma imkânı sağlanmıștır. Sertifika sahipleri, yeterli miktarda sertifikaya sahip olmaları halinde dilerlerse projeden tapu alabilecekleri gibi (asli edim), hisseleri oranında gayrimenkulün getirisine de ortak olabilirler (tali edim). Yine asli edim talep etmeyen yatırımcılar, proje bitiminden önce borsada sertifikalarını satarak nakde çevirebilirler. Gayrimenkul sertifikası ihraç eden taraf, alternatif bir finansman kaynağına sahip olmaktadır. Gayrimenkul sertifikaları sayesinde henüz inșasına bașlanmayan yeni konut projelerinin ya da kentsel dönüșüm projelerinin finansmanının sağlanması mümkün hale gelmektedir.

Türkiye'deki konut sorunun bir yönü, kentsel dönüșüm yoluyla sorunlu konutların iyileștirilmesi ve diğer yönü ise dar gelirlilerin konut sahibi olabilmesidir. Gayrimenkul sertifikası modeli, kentsel dönüșümde uygulanması daha uygun bir araçken; dar gelirlilerin konut sorununu çözmekten daha uzaktır. Bunun yerine orta ve üst gelir grubu ya da belli bir birikime sahip tasarruf sahiplerinin yararlanabileceği bir gayrimenkul sahibi olma aracı olarak değerlendirilebilir. Kentsel dönüșüm açısından, dönüștürülecek olan eski konutların sahiplerine -örneğin 100 m2 konut için 100 adet sertifika verilmesi gibi- bu konutların metrekareleri kadar gayrimenkul sertifikasının bedelsiz olarak verilmesi yoluyla gayrimenkul sertifikalarına bașvurulabilir (Köroğlu, 2016: 35). Böylece hem konut sahiplerinin haklarının korunması hem de dönüșüm projelerinin artması ve hızlı șekilde bitirilesi mümkün olacaktır. Ancak eski konut sahibinin yenileme maliyetini karșılaması noktasında bir sorun ortaya çıkmaktadır. Bu ek maliyet, ya eski konut sahibinin varsa kendi imkânlarıyla ya da hukuki ve teknik açıdan mümkünse eski konut alanına daha çok konut inșa edilmesi yoluyla karșılanabilir. Bu açıdan yeni bir alanda veya büyük çaplı projelerde gerçekleștirilecek dönüșüm projeleri için gayrimenkul sertifikalarının uygulanması daha elverișli gözükmektedir (Köroğlu, 2016: 35).

\subsubsection{Gecekondu Dönüșüm Sertifikası}

Gecekondunun kendisi bizzat konut sorununun çözümüne yönelik kayıt dıșı bir üretim ve finansman yöntemidir. Geçmiște, kentteki konut stokunun yașanan hızlı göçü karșılayamaması nedeniyle bir anlamda zaruri olarak ortaya çıkan gecekondu, günümüzde neredeyse tamamen 
piyasaya yönelik olarak üretilmektedir. Gecekondu alanlarının yarattığı ekonomik ve sosyal sorunlar, bu alanların dönüștürülmesini zorunlu kılmaktadır. Bu sorunun çözümüne yönelik uygulanabilecek menkulleștirme yöntemlerinden biri, gecekondu dönüșüm sertifikası uygulamasıdır. Gecekondu sahibine tapu tahsis belgesi ya da imar hakkı yerine, belirlenen nominal bedel üzerinden gecekondu dönüșüm sertifikası verilmesi esasına dayanır. Menkulleștirme yoluyla yaratılan değer, gerek mevcut gecekondu alanında veya bașka bir alanda geliștirilecek bir proje için kullanılabilir (Uslu ve Uzun, 2014: 9). Kamuya ait toprakların ișgal edilmesi sonucu elde edilen gecekonduların zamanla kıymetli konut alanlarıyla birleșmesi ya da önemli kent alanlarında yer alması gibi nedenlerle artan değerine gecekondu sahiplerinin bu tür menkulleștirme yöntemleriyle ortak edilmesinin, en az önceki gecekondu afları kadar adaletsiz bir uygulama olacağı açıktır. Bu açıdan kentsel dönüșümde meșru konut sahiplerini mağdur etmeyecek bir finansman yapısının sağlanması ön planda tutulmalıdır. Bunun dișında özellikle kamusal uygulamalar sonucu artan kentsel ranttan devletin en fazla fayda elde eden taraf olmasının sağlanması da gerekmektedir.

\subsection{7. İmar Haklarını Toplulaștırma Sertifikası}

İmar haklarının toplulaștırılması, parsel bazında var olan imar haklarının proje bazında bir araya getirilmesi yoluyla toplulaștırılmasıdır. Böylece imar hakkı sahipleri, gerçekleștirilen projede yaratılacak değer üzerinden pay almaktadır.

Türkiye'de uygulamanın ilk örneği Ankara'da Portakal Çiçeği Vadisi Projesinde görülmektedir. Gerçekleștirilen proje alanında arsa sahiplerinden belediyenin payı ve diğer arsa sahiplerinin payları birleștirilmiș, projeyi gerçekleștirecek șirkete de hisse temsilinde pay verilmiștir (Göksu, 2003). Parsel bazında yapılașma yerine toplulaștırma sonucu proje bazında yapılașmanın sağlanması, ortaya çıkacak değerin parsel bazında yaratılacak değerin çok daha üstünde olmasını sağlayacaktır. Böylece paydașların elde edeceği getiri de daha yüksek olacaktır. Portakal Çiçeği Projesi özelinde değerlendirecek olursak belirtilen sonuçlara ulașıldığı söylenebilir. Ayrıca kamulaștırmaya bașvurulsaydı büyük bir kaynak ayrılmak zorunda kalınacakken, piyasa finansman koșullarından faydalanılması ile kaynak ayırmadan daha fazla kamu yararı yaratılmıștır. Her finansman yöntemi her proje için uygun olmayabilir. Dönüșüm projesi uygulanacak alanın özellikleri -parsel yapısı, arazi genișliği, paydaș sayısı, kent merkezine uzaklığı, gecekondu alanlarının ya da 
tarihi, kültürel yapıların varlığı, ticari canlılık vb.- yukarda bahsedilen yöntemlerden en uygun olanın seçilmesi için belirleyici olacaktır. Örneğin Ankara'da Portakal Çiçeği Projesi sonrasında Dikmen Vadisinde de aynı yöntem uygulanmaya çalıșılmıș ancak bașarılı olamayınca belediye yurtdıșına tahvil ihraç ederek projenin finansmanını sağlayabilmiștir.

\subsection{Değer Yakalama Yöntemlerini Kullanarak Vergisel Müdahale}

Kentsel dönüșüm finansmanı açısından kentsel dönüșüm sonucu ortaya çıkan artı değerden kamunun pay almasının sağlanması dönüșüm uygulamalarının sürekliliği açısından çok önemlidir. Ancak ülkemizde bu artı değerden pay alınabilmesi için geliștirilmiș ve uygulanan değer yakalama yöntemleri bulunmamaktadır.

Kentsel dönüșümün finansmanı için çeșitli değer yakalama (value capture) yöntemleri kullanılabilir. Değer yakalama, kamu müdahaleleri nedeniyle arazi ve binaların değerindeki artıșların bir kısmının kamuya aktarılması anlamını tașır. Olușan ek değer, bina/arazi sahibinin doğrudan yatırımları dıșındaki faaliyetler nedeniyle ortaya çıkmaktadır. Değer yakalama yöntemleri, kamu açısından düșük bir kaynak aktarımıyla bile yeni projelerin gerçekleștirilebilmesini sağlar. Kentsel dönüșüme doğrudan finansman desteği sağlayacak en önemli değer yakalama yöntemleri, arazi değer vergisi, iyileștirme vergisi ve vergi artıș finansmanı olarak ele alınmıștır. Araziye dayalı finansman araçları kullanılırken kentsel arazi değerlerindeki volatiliteye ve olușmuș olabilecek balon fiyatlara dikkat etmek gerektiği vurgulanmalıdır. Gelecekteki arazi değer artıșlarının gerçekçi olmayan beklentilerine bağlanarak yapılacak yatırımlar, bütçeyi olumsuz etkileme riskini barındırmaktadır (Peterson, 2008: 4).

\subsubsection{Arazi Değeri Vergisi (Land Value Tax)}

Belirli bir projeden ziyade kamu mal ve hizmetlerinin sağlanmasıyla yaratılan daha genel bir değeri yakalamak için tasarlanmıș bir değer yakalama tekniğidir. Mülk değerinden ziyade arazi değerini değerlendirir ve arazi sahiplerine odaklanır. Henry George, 1879 tarihli ilerleme ve Yoksulluk kitabında ABD'deki ekonomik ilerlemelere karșın yoksulluğun devam etme sebebinin temelde arazi sahipleri ve arazi spekülasyonları olduğunu belirterek; çözüm olarak arazi sahiplerinin sağladığı rant üzerine konulacak bir "tek vergi" önermiștir (Dye ve England, 2010:7). Buna göre her mülk sahibi, arazi rantının değerine göre aylık bir rant vergisi ile yükümlü olacaktır. Toprak iyileștirmeleri veya inșaatlar üzerine herhangi bir vergi konmayacaktır (Skousen, 2003: 254). 
George'a göre arazi değeri üzerindeki vergi, spekülatif rantı yok ederek üretimi arttırmaktadır. Modern ekonomik teori ise arazi değeri vergisinin șu anda yatırım yapmak ya da daha sonra yatırım yapmayı beklemek arasındaki tercihte tarafsız olduğu sonucuna varmaktadır. Binaların vergilendirilmesi yerine arazi üzerine bir vergi konulması, sabit arazi arzı nedeniyle daha az bozulmaya yol açacaktır. Kısaca verginin saptırıcı özelliği azalacak ve tarafsız bir vergi özelliğine yaklașacaktır.

\subsection{2. İileștirme Vergileri (Betterment Tax)}

"Iyileștirme vergisi/harcı" veya "iyileștirme ücreti- betterment levy", arazi değer kazancı üzerinden tek seferlik ya da yıllık bir vergi alınması yoluyla genellikle altyapı yatırım maliyetlerini karșılayacak bir fon sağlamak amacıyla alınır. Kentsel ulașım, kaldırımlar, parklar ve su/ atık su gibi alanlar için kullanılabilir. Altyapı yatırımlarından olumlu etkilenen mülk sahiplerine yansıyan özel arazi varlıklarındaki katma değeri geri kazanmak üzere tasarlanmıș adil ve verimli bir vergi olarak ifade edilmektedir (WEF, 2014: 27). lyileștirme mekanizmasının en kayda değer avantajı, altyapı finansmanının yükünü genel halktan, doğrudan fayda elde eden mülklere kaydırmasıdır. (Medda ve Modelewska 2009: 7)

Ülkemizde șerefiye olarak isimlendirilen gelirlere benzetilebilecek iyileștirme vergilerinin farklı ülkelerde farklı isimlerle uygulanan çeșitlerinden bahsetmek mümkündür. Örneğin $A B D^{\prime}$ de özel değerlendirme bölgelerinde "özel değerlendirme- special assessment" adı verilen bir iyileștirme harcı çeșidi kullanılmaktadır. Bu bölgelerde, kamu altyapı iyileștirmesinin yol açtığı arazi değerindeki artıșla ilgili alınan değerlendirme harcı, daha sonra o yatırım için sermaye piyasalarından sağlanmıș borcu ödemek için kullanılmaktadır (WB, 2018).

Diğer değer yakalama yöntemlerinden olan "geliștirme harçlarıdevelopment fees" veya "etki harçları- impact fees" bütçelerin harcama tarafında ișlev görürken; iyileștirme vergileri, zaten maruz kalınan altyapı yatııımı maliyetlerinin bir kısmını geri almaya çalıșır. Belirtilen vergilerin/harçların uygulanmasındaki temel sorunlardan biri, altyapı yatırımlarından kaynaklanan arazi değeri artıșının ölçülmesinin zorluğudur. Bu vergiler, hizmetlerin bedelini ödeyebilen kentin varlıklı bölgelerine daha çok altyapı yatırımı yapılmasına neden olacağı için de eleștirilmektedir. 


\subsubsection{Vergi Artıș Finansmanı (Tax Increment Financing- TIF)}

Arsa değer vergileri, arsa değerindeki; TIF ise emlak değerindeki artıșlardan elde edilen faydanın ölçülmesine dayanır. TIF, yeniden canlandırmaya ihtiyaç duyulan alanların yeniden geliștirilmesi ve ișlevini yitirmiș sanayi alanlarının (brownfield) iyileștirilmesini tevik etmek için $A B D^{\prime}$ de yaygın bir sekilde kullanılan bir ekonomik kalkınma aracıdır. Brownfield, sıklıkla kullanılmayan, boș ve bozulmuș olan kentsel bölgelerdir. Altyapının genel olarak yer aldığı șehir alanlarına yakınlığı nedeniyle bu alanlar, yeniden geliștirme için büyük bir potansiyel barındırmaktadır. Bununla birlikte, bu potansiyelin gerçekleștirilmesi, kirlenmiș arazilerin temizleme maliyetleri, mevcut fakat eski altyapının iyileștirilmesi veya değiștirilmesi maliyetleri nedeniyle ertelenmektedir. Pek çok durumda, geleneksel özel finansman kaynakları, yeniden yapılanma ile ilgili risklerden dolayı bu alanlara yatırım yapmakta tereddüt etmektedir. Gelecekteki karlar açısından potansiyel olmasına rağmen ișlevini yitirmiș bu sanayi alanları, genellikle peșin yeniden geliștirme finansman eksikliği nedeniyle kullanılmayarak kalır.

Illk kez 1952'de Kaliforniya'da uygulanan TIF, ABD'de neredeyse diğer bütün eyaletlerde kullanılmaktadır. Örneğin Chicago'da tüm emlak vergilerinin yüzde 10'u TIF amaçları için ayrılmıștır ve TIF bölgeleri, kentin coğrafi bölgesinin yüzde 25'inden fazlasını kapsamaktadır (Slack, 2016: 26). TIF, geliștirme ile ilgili maliyetleri finanse etmek için geliștirme kapsamında olușan emlak değerindeki artıșa uygulanan vergilerdir. En çok yerel yönetimler tarafından belirlenen mahallelerde konut, ekonomik kalkınma ve yeniden yapılanmayı teșvik etmek için kullanılır. Bazı durumlarda ulașım projelerini finanse etmek amacıyla da uygulanır (CTS, 2009: iii). Kentler, sermaye iyileștirmeleri için bir TIF bölgesi belirlemekte ve daha sonra altyapı ve diğer ekonomik kalkınma girișimlerine yapılacak yatırımları ödemek için emlak vergilerindeki gelecekteki büyümeyi ayırmaktadır (Slack, 2016: 27). TIF ile altyapı iyileștirmeleri için fon sağlamak amacıyla emlak vergisi gelirlerindeki beklenen büyüme güvence alına alınmıștır (Medda ve Modelewska, 2009:6). TIF'ler sübvansiyonlar veya vergi indirimleri değildir. Bir TIF kapsamında geliștirme, yerel yönetim sübvansiyonundan değil, geliștirme sonucunda üretilen vergi gelirlerindeki artıșlardan finanse edilmektedir. Yerel yönetimlerden ișletmelere fon transferi yapılmaz veya bir ișletmeden diğerine transfer yoktur. Değerlendirme tabanındaki artıștan elde edilen vergiler, bölgedeki kamu iyileștirmelerini finanse etmek için kullanılmaktadır (Slack, 2016: 27). 


\section{Sonuc}

Kentsel politikalar, kentin fiziki olarak planlanması, altyapının iyileștirilmesi, kentsel gelișim, kent ekonomisi, kentteki gündelik yașamın düzenlenmesi ve kent kültürünün gelișimiyle ilgilidir. Kent planlamasında yer alan güvenlik, ulașım, enerii verimliliği/ yenilenebilir enerji, kentsel çevre ve estetik, kültürlerarası etkileșim gibi kentsel politikanın odağındaki amaçların gerçekleștirilmesi açısından kentsel dönüșüm uygulamaları önemli bir araçtır. Kentsel dönüșüme bașvurulma nedenlerine ve dönüșümün gerçekleșeceği kentsel alan ve yapılara uygun düzenlemelerin ve finansman yöntemlerinin geliștirilmesi gerekmektedir. Çalıșmada kentsel dönüșüme yönelik kamusal müdahale, yapılan hukuki düzenlemeler, kamu özel kesim ortaklıklarının kullanılması, gayrimenkule dayalı sermaye piyasası araçlarının düzenlenmesi ve değer yakalama yöntemlerinin kullanılması çerçevesinde ele alınmıștır.

Kentsel dönüșümün finans boyutu, kentsel dönüșümü gerçekleștirecek tarafları-kamu ve yatırımcılar- ve kentsel dönüșümden etkilenecek bireyleri kapsamaktadır. Bu doğrultuda devletin sağladığı kredi ve kira yardımı gibi uygulamalar, sermaye piyasası araçları ve çeșitli hukuki düzenlemeler bulunmaktadır. Ancak hem konut yetersizliği hem de var olanların dönüștürülmesi ihtiyacl, konut ve kentsel dönüșüm finansmanı araçlarının yaygınlaștııılmasını gerektirmektedir. Çalıșmada, Türkiye'de uygulanmaya yeni bașlayan ya da henüz uygulanmayan bazı araçlara yer verilmiștir. Bunlardan gayrimenkul geliștiriciler için alternatif finansman imkânı ve yatırımcılar için gayrimenkule dayalı kazanç elde imkânı sunan yatırım araçlarından sisteme uyarlanabilecek olan yöntemler, Türkiye'deki kentsel dönüșümün geliștirilmesi açısından değerlendirilebilir.

Yerel yönetimlerin kentsel dönüșümle ilgili önemli bir rolleri bulunmaktadır. Ancak Türkiye'de belediyelerin öz gelirlerinin yetersiz olduğu ve harcamaların büyük kısmının merkezi yönetim gelirlerinden aktarılan paylarla gerçekleștirildiği bilinmektedir (Ökmen ve Koç, 2015: 554). Belediye öz gelirlerinin arttırılmasının yollarından biri, uygulamaya konulacak yeni finansman araçlarıdır. Bu doğrultuda kentsel dönüșüm amacına uygun olabilecek bazı finansman yöntemleri ele alınmıștır. Arazi değer vergisi, iyileștirme vergileri ve vergi artıș finansmanı olarak ele alının değer yakalama yöntemleri, kentsel rantın vergilendirilmesi amacını tașımaktadır. Kentsel rantın vergilendirilmesi ile belediyelerin önemli sorunlarından biri olan finansman yetersizliğine katkı sağlanmıș olacaktır. Aynı șekilde arsa spekülasyonlarının ve spekülatif kazançların önüne 
geçmek ve planlıv ve daha sağlıklı kentsel alanların olușması da mümkün olacaktır. Bu gelir çeșitlerinin bașta İstanbul olmak üzere kentsel rantın yüksek olduğu metropoliten alanlarda uygulanabilmesine ilișkin hukuki bir düzenleme yapılması önerilebilir.

Kentsel dönüșümle ilgili nicel verilerin -dönüșüme giren yapı sayısı, yapılan konut sayısı, dönüșümden etkilenen hanehalkı sayısı gibi- topluca yer aldığı resmi bir birimin olmaması da önemli bir sorundur. Aynı șekilde kentsel dönüșüm sonucu elde edilen sosyal faydayı belirlemeye yararlı olacak bir veriye ulașmak șu an itibariyle mümkün olmamaktadır. Bu açıdan TOKI benzeri ancak sadece kentsel dönüșümle ilgili faaliyetleri gerçekleștiren, bu alandaki belediye ve özel sektör çalıșmalarını izleyen, verileri toplayan, süreçleri raporlayan ve tarafları koordine eden düzenleyici ve denetleyici bir üst kurul șeklinde bir birimin kurulması önerilebilir. Ayrıca hem kentsel dönüșüm projelerine uzun vadeli ödeme desteği sunan hem de gayrimenkule dayalı menkulleștirme hizmeti sağlayan, bu alanda uzmanlașmıș bir bankanın kurulması da faydalı olacaktır.

Güçlü bir yasal çerçeve ile gelișmiș birincil ve ikincil piyasaların varlığı, konut finansmanını ulașılabilir hale getirecektir. Ancak gerekli altyapı kuruluncaya kadar fonlama maliyetlerinin yüksek olacağı ve finansman alıșkanlıklarının hemen değișmeyeceği göz önüne alınarak bu alandaki adımların hızlandırılması gerekmektedir. 


\section{KAYNAKCA}

Adair A., Berry J., Mcgreal S., Deddis B., Hirst S. (2000). The Financing Of Urban Regeneration. Land Use Policy (17) 147-156.

Amirtahmasebi, R. vd. (2016). Regenerating Urban Land: A Practitioner's Guide To Leveraging Private Investment.Urban Development; World Bank, Washington.

Ataöv A., Osmay S. (2007). Türkiye'de Kentsel Dönüșüme Yöntemsel Bir Yaklașım. Metu Jfa, 24/ 2, 57-82.

Ayhan, F. (2013). Kentsel Dönüșüm Kavramı ve Tarihsel Gelișimi. Kentsel Dönüșüm Hukuku (Edit: Yasin, Melikșah ve Șahin, Cenk) İstanbul Üniversitesi S.S.Onar İdare Hukuku ve illimleri Araștırma ve Uygulama Merkezi Yayınları, No:2013/1.

CABERNET (Concerted Action on Brownfield and Economic Regeneration Network) (2005), State Aid Action Plan: Consultation Document. http://ec.europa.eu/competition/state_aid/reform/comments_saap/37279.pdf (13.09.2017).

Coșkun, Y. (2015). Türkiye'de Konut Finansmanı: Sorunlar ve Çözüm Önerileri, Türkiye Bankalar Birliği Yayın No: 310.

Coșkun, Y. (2016). Kentsel Dönüșümün Kent ve Ülke Ekonomisine Etkileri. http://gayrimenkulturkiye.com/2016/03/04/kentsel-donusumun-kent-ve-ulke-ekonomisine-etkileri/ (01.01.2018).

Couch, C. vd. (Eds.) (2003). Urban Regeneration İn Europe. Oxford: Blackwell Publishing.

ÇȘB (2014). Kentsel Dönüșüm İçin İmar Hakkı Transferi Geliyor. http://www.csb.gov. tr/turkce/?Sayfa=faaliyetdetay\&ld= 1134 (28.05.2018).

CTS (Center for Transportation Studies) (2009). Value Capture for Transportation Finance.

Dye, R. F. \& England, R. W. (2010). Assessing the Theory and Practice of Land Value Taxation. Lincoln Institute of Land Policy. Policy Focus Report/Code PF025.

Medda, F. R. \& Modelewska, Marta (2009). Land Value Capture As A Fundıng Source For Urban Investment: The Warsaw Metro System. Better Government Program 2009-10.

Gale, D. E. (1977). The Transfer of Development Rights: Some Equity Considerations. 14 Urban Law Ann., 81-100.

Genç, F. N. (2008). Türkiye'de Kentsel Dönüșüm: Mevzuat ve Uygulamaların Genel Görünümü. Yönetim ve Ekonomi, (15), 115-130.

Göksu, A. F. (2003) Kentsel Dönüșüm Projelerinde Yenilikçi Yaklașımlar. 11-13 Haziran, Yıldız Teknik Üniversitesi, Kentsel Dönüșüm Sempozyumu.

Görgülü vd. (2006). Mahalle Ölçeğinde Kentsel Dönüșüm Modeli - Küçükbakkalköy Örneği. İstanbul'un Eylem Planlamasına Yönelik Mekânsal Gelișme Stratejileri Araștırma ve Model Geliștirme İși, YTÜ, ȘBPB, İstanbul.

Hacribrahimoğlu, N. (2013). Kentsel Dönüșüm Yöntemleri. Kentsel Dönüșüm Hukuku (Edit: Yasin, Melikșah \& Șahin, Cenk) İstanbul Üniversitesi S.S.ONAR İdare Hukuku ve İlimleri Araștırma ve Uygulama Merkezi Yayınları, No:2013/1. 
Hazine Müsteșarlığı (2018). Kira Sertifikası Yatırımcı Kılavuzu. https://www.hazine. gov.tr/File/?path...̇̇çin+Bilgiler\%2Fkira_sertifikasi_kilavuz.pdf (20.04.2018).

Hodge, G. A. \& Greve, C. (2007). Public-Private Partnerships: An İnternational Performance Review. Public Administration Review. 67(3), 545-558.

Jung, T. H. vd. (2015) The Role Of Stakeholder Collaboration In Culture-Led Urban Regeneration: A Case Study Of The Gwangju Project, Korea. Cities (44) 29-39.

Kalkınma Bakanlığı (2015), Kamu Özel İșbirliği Mevzuatı, Yatırım Programlama İzleme ve Değerlendirme Genel Müdürlüğü.

Köroğlu, A. (2016). Gayrimenkul Sertifikası Modeli ve Türkiye'de Uygulanabilirliği. Gazi iktisat ve İșletme Dergisi. 2/1, 25-42.

Kennedy, M. \& Leonard, P. (2001). Dealing With Neighborhood Change: A Primer On Gentrification And Policy Choices, A Discussion Paper Prepared For The Brookings Institution Center On Urban And Metropolitan Policy.

Makas, A. C., (2012). Kentsel Dönüșüm Yasası ve Finansman Boyutu, Kentsel Dönüșümde Sürdürülebilir Yașam Kalitesi İçin Farkındalık Araștırması, İktisadî Araștırmalar Vakfı, 213, İstanbul.

Mataracı, O. vd. (2017). Kentsel Dönüșümde Alternatif Bir Yöntem: İmar Hakkı Transferi. TMMOB Harita ve Kadastro Mühendisleri Odası, 16. Türkiye Harita Bilimsel ve Teknik Kurultayı, 3-6 Mayıs, Ankara.

Ökmen, M. \& Koç, N. (2015). Türkiye'de Belediye Gelirleri İçinde Borçlanma ve Borçların Azaltılması İçin Öneriler. Yönetim ve Ekonomi. Cilt:22(2), 551-565.

Özgüç, E. (2008). Gayrimenkul Yatırım Fonları: Ceșitli Ülkelerdeki Uygulamalar ve Türkiye İçin Öneriler, Sermaye Piyasası Kurulu Araștırma Raporu.

Özkul, M. (2017). Dünyada ve Türkiye'de Kentsel Dönüșüm Projelerinin Finansman Yöntemleri. Illler Bankası Anonim Șirketi Uzmanlık Tezi.

Peterson, G. (2008). Unlocking Land Values To Finance Urban İnfrastructure Land-Based Financing Options For Cities. Gridlines, Note no 40.

Roberts P. \& Sykes, H. (Eds) (2000) Urban Regeneration A Handbook. Sage Publications.

Skousen, M. (2003). İktisadî Düșünce Tarihi Modern Ilktisadın İnșası (Çev. Acar, M. vd.) Adres Yayınları.

Slack, E. (2016) Improving Local Government Revenue In Nsw: What Are The Options?, International Keynote and Discussion Paper for the Local Government NSW Finance Summit.

Solmaz, E. (2013). Kentsel Dönüșüm Finansman Yöntemleri", Kentsel Dönüșüm Hukuku (Edit: Yasin, M. Șahin, C.(2013) İstanbul Üniversitesi S.S.Onar İdare Hukuku ve ilimleri Araștırma ve Uygulama Merkezi Yayınları, No:2013/1.

Sönmez, N. Ö. (2006). Düzensiz Konut Alanlarında Kentsel Dönüșüm Modelleri Üzerine Bir Değerlendirme. Planlama, 2.

SPK (2007). Gayrimenkul Yatırım Ortaklıkları, SPK Yatırımcı Bilgilendirme Kitapçıkları-5, Ankara. 
Șahin, Ö. (2012). Eski Sanayi Alanları Dönüșümünde Ortaklık Modeli Önerisi: Kartal Örneği, İstanbul Teknik Üniversitesi, Fen Bilimleri Enstitüsü Dokłora Tezi.

Șarkaya, C. (2007). Gayrimenkul Yatırım Ortaklıkları Üzerine Bir İnceleme ve Türkiye'ye ilișkin Sektör Analizi. Sosyal Bilimler Dergisi (1), 175-190.

Șimșek, C. \& Çakıroğlu, B. (2017). Gayrimenkul Yatırım Fonları. GSI Articletter, Summer, 87-102.

TÜiK (2011). Nüfus ve Konut Araștırması. http://www.tuik.gov.tr/Kitap. do?metod=KitapDetay\&KT_ID=1 1\&KITAP_ID=276 (01.03.2018).

Uslu G. \& Uzun B. (2014). Kentsel Dönüșüm Projelerinde Deprem Ełkisi. Harita Teknolojileri Elektronik Dergisi. 6(2) 1-11.

WEF (World Economic Forum) (2014) Accelerating Infrastructure Delivery New Evidence from International Financial Institutions. http://www3.weforum.org/docs/ WEF_AcceleratingInfrastructureDelivery_2014.pdf (30.04.2018).

WB (Worldbank) (2018). Betterment Levies, https://urban-regeneration.worldbank. org/node/15 (01.05.2018). 
